\title{
A New Proof Of The Maximum Principle
}

\author{
Ngo Van Long and Koji Shimomura
}

Série Scientifique

Scientific Series

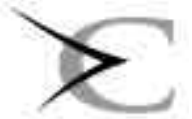

CIRANO

Montréal

Janvier 2002 


\section{CIRANO}

Le CIRANO est un organisme sans but lucratif constitué en vertu de la Loi des compagnies du Québec. Le financement de son infrastructure et de ses activités de recherche provient des cotisations de ses organisationsmembres, d'une subvention d'infrastructure du ministère de la Recherche, de la Science et de la Technologie, de même que des subventions et mandats obtenus par ses équipes de recherche.

CIRANO is a private non-profit organization incorporated under the Québec Companies Act. Its infrastructure and research activities are funded through fees paid by member organizations, an infrastructure grant from the Ministère de la Recherche, de la Science et de la Technologie, and grants and research mandates obtained by its research teams.

\section{Les organisations-partenaires / The Partner Organizations}

-École des Hautes Études Commerciales

-École Polytechnique de Montréal

-Université Concordia

-Université de Montréal

-Université du Québec à Montréal

-Université Laval

-Université McGill

-Ministère des Finances du Québec

-MRST

-Alcan inc.

- AXA Canada

-Banque du Canada

-Banque Laurentienne du Canada

- Banque Nationale du Canada

- Banque Royale du Canada

- Bell Canada

- Bombardier

-Bourse de Montréal

-Développement des ressources humaines Canada (DRHC)

-Fédération des caisses Desjardins du Québec

-Hydro-Québec

-Industrie Canada

-Pratt \& Whitney Canada Inc.

-Raymond Chabot Grant Thornton

-Ville de Montréal

(C) 2002 Ngo Van Long et Koji Shimomura. Tous droits réservés. All rights reserved. Reproduction partielle permise avec citation du document source, incluant la notice $\mathbb{~}$.

Short sections may be quoted without explicit permission, if full credit, including (C) notice, is given to the source.

Ce document est publié dans l'intention de rendre accessibles les résultats préliminaires de la recherche effectuée au CIRANO, afin de susciter des échanges et des suggestions. Les idées et les opinions émises sont sous l'unique responsabilité des auteurs, et ne représentent pas nécessairement les positions du CIRANO ou de ses partenaires.

This paper presents preliminary research carried out at CIRANO and aims at encouraging discussion and comment. The observations and viewpoints expressed are the sole responsibility of the authors. They do not necessarily represent positions of CIRANO or its partners. 


\title{
A New Proof Of The Maximum Principle
}

\author{
Ngo Van Long* and Koji Shimomura ${ }^{\dagger}$
}

\section{Résumé / Abstract}

Nous donnons une preuve nouvelle du principe de maximum pour les problèmes de contrôle optimal aux points terminaux fixés. Le cas où il y a des contraintes en forme d'inégalité est permis. Notre preuve utilise le théorème de l'enveloppe.

We offer a new proof of the maximum principle for optimal control problems with fixed endpoint. We allow for inequality constraints involving state variables and control variables. Our proof relies on an application of the envelope theorem.

Key Words: Maximum Principle, Envelope Theorem

Mots Clés: Principe de Maximum, Théorème de l'Enveloppe

JEL Classification: C61

\footnotetext{
Corresponding author: Ngo Van Long, CIRANO, and Department of Economics, McGill University, email: longn@cirano.qc.ca

Koji Shimomura: Research Institute foe Economics and Business Administration, Kobe University, email: simomura@rieb.kobe-u.ac.jp.
} 


\section{Introduction}

The purpose of this note is to offer a new and simple proof of the maximum principle, using the envelope theorem ${ }^{1}$. A number of authors have provided proofs of the maximum principle using the idea that a small deviation from the optimal path of the control variable must have a negative impact on the value of the objective function (see, for example, Kamien and Schwartz, 1991, pp 124-7, Leonard and Long, 1992, pp 161-3). The proof by Kamien and Schwartz relies on the assumption of a "free value of the state variable at the terminal point" (p.124) while Leonard and Long, dealing with a fixed value of the state variable at the terminal point, assume the existence of a class of deviation function with some special properties. The proof that we offer below does not rely on either of these assumptions ${ }^{2}$.

\section{A proof based on the envelope theorem}

Let $k=\left(k_{1}, \ldots, k_{n}\right)$ denote the vector of state variables and $z=\left(z_{1}, \ldots, z_{m}\right)$ denote the vector of control variables. The transition equation, in vector notation, is

$$
\dot{k}=g(k, z, t)
$$

where $g($.$) have continuous partial derivatives. Given k$ and $t$, the control vector is restricted to belong to some set $A(k, t)$. We assume that this set can be described by

$$
A(k, t)=\{z: \phi(k, z, t) \geq 0\}
$$

where $\phi=\left(\phi_{1}, \ldots, \phi_{s}\right)$ is a vector of $s$ differentiable functions. The objective function is

$$
\max \int_{0}^{T} U(k, z, t) d t
$$

subject to (1), $z \in A(k, t)$, and the boundary conditions $k(0)=k_{0}$ (given) and $k(T)=k_{T}$ (fixed).

In the special case where it is possible to invert (1) to obtain $z=h(k, \dot{k}, t)$, one can substitute for $z$ and apply the calculus of variations. In general, however, such inversion is not possible (for example, when the number of control variables exceed the number of state variables). In this note we deal with the general case.

Let $\left(k^{*}(t), z^{*}(t)\right)$ be an optimal time path, i.e., a solution to problem (2). Then at any time $t$, given $k^{*}(t)$ and $\dot{k}^{*}(t)$, it must be the case that $z^{*}(t)$ solves the static problem

$$
\max _{z} U\left(k^{*}(t), z, t\right)
$$

\footnotetext{
${ }^{1}$ After completing this paper, we discovered that a similar proof is offered in Dana and Le Van (2001). The main feature that distinguishes our approach from theirs is our direct application of the envelope theorem, a tool that many economic researchers have found useful.

${ }^{2}$ Other economists, such as Arrow and Kurz (1970), Silberberg (1990, pp. 620-621), proved the maximum principle by using the Hamilton-Jacobi-Bellman equation. Such an approach relies on the assumption of a twice-differentiable value function. Our proof does not rely on that assumption.
} 
subject to the equality constraint

$$
g\left(k^{*}(t), z, t\right)-\dot{k}^{*}(t)=0
$$

and the inequality constraint

$$
\phi\left(k^{*}(t), z, t\right) \geq 0 \text {. }
$$

We apply the Kuhn-Tucker theory to the static problem (3). Here, we omit the asterisk to lighten notation. We assume that the constraint qualifications hold (see, for example, Takayama, 1985, p 101). Then there exists a vector $(\lambda, \mu)$ with which we can form the Lagrangian function

$$
\begin{gathered}
L(z, \lambda, \mu ; k(t), \dot{k}(t), t)= \\
U(k(t), z, t)+\lambda[g(k(t), z, t)-\dot{k}(t)]+\mu \phi(k(t), z, t)
\end{gathered}
$$

and obtain the necessary conditions:

$$
\begin{gathered}
L_{z}=U_{z}+\lambda g_{z}+\mu \phi_{z}=0 \\
L_{\mu}=\phi(k(t), z, t) \geq 0, \mu \geq 0, \mu \phi(k(t), z, t)=0 \\
L_{\lambda}=g(k(t), z, t)-\dot{k}(t)=0
\end{gathered}
$$

The solution to this system of equation is denoted by $z=z(k(t), \dot{k}(t), t), \lambda=$ $\lambda(k(t), \dot{k}(t), t), \mu=\mu(k(t), \dot{k}(t), t)$. Now, by appealing to the Envelope Theorem (see, for example, Takayama, 1985, p 138) we have

$$
\begin{gathered}
\frac{\partial}{\partial k(t)} U(k(t), z(k(t), \dot{k}(t), t), t)=\frac{\partial}{\partial k(t)} L(z, \lambda, \mu ; k(t), \dot{k}(t), t) \\
=U_{k}+\lambda g_{k}+\mu \phi_{k} \\
\frac{\partial}{\partial \dot{k}(t)} U(k(t), z(k(t), \dot{k}(t), t), t)=\frac{\partial}{\partial \dot{k}(t)} L(z, \lambda, \mu ; k(t), \dot{k}(t), t) \\
=-\lambda(k(t), \dot{k}(t), t)
\end{gathered}
$$

Now, let us return to the dynamic optimization problem (2), with $z=$ $z(k(t), \dot{k}(t), t)$. That is, we seek to maximize

$$
\int_{0}^{T} U(k(t), z(k(t), \dot{k}(t), t), t) d t \equiv \int_{0}^{T} F(k(t), \dot{k}(t), t) d t
$$

subject to the boundary conditions are $k(0)=k_{0}$ (given) and $k(T)=k_{T}$ (fixed). The following Euler-Lagrange condition is necessary for an optimal solution:

$$
\frac{d}{d t}\left[F_{\dot{k}}\right]=\frac{\partial F}{\partial k}
$$


Substituting (11) into the left-hand side of (12) and (10) into the right-hand side of (12), we get:

$$
-\frac{d}{d t} \lambda\left(k^{*}(t), \dot{k}^{*}(t), t\right)=U_{k}+\lambda g_{k}+\mu \phi_{k}
$$

Let us we define

$$
\lambda^{*}(t)=\lambda\left(k^{*}(t), \dot{k}^{*}(t), t\right) \text { and } \mu^{*}(t)=\mu\left(k^{*}(t), \dot{k}^{*}(t), t\right)
$$

and

$$
\begin{gathered}
\mathcal{H}\left(k, z, \lambda^{*}, t\right)=U(k, z, t)+\lambda^{*} g(k, z, t) \\
\mathcal{L}\left(k, z, \lambda^{*}, \mu^{*}, t\right)=\mathcal{H}\left(k, z, \lambda^{*}, t\right)+\mu^{*} \phi\left(k, z, \lambda^{*}, \mu^{*}, t\right)
\end{gathered}
$$

Then, from the definitions (14)-(15), the equations (7)-(9) and (13), we obtain the necessary conditions that constitute the maximin principle:

$$
\begin{gathered}
\frac{\partial \mathcal{L}}{\partial z}=\frac{\partial \mathcal{H}}{\partial z}+\mu^{*} \frac{\partial \phi}{\partial z}=0 \\
\dot{\lambda}=-\frac{\partial \mathcal{L}}{\partial k} \\
\dot{k}=\frac{\partial \mathcal{L}}{\partial \lambda}
\end{gathered}
$$

This concludes our proof of the maximum principle.

\section{References}

[1] Arrow, Kenneth and M. Kurz,1970,.Public Investment, the Rate of Return and Optimal Fiscal Policy, Johns Hopkins Press, Baltimore

[2] Dana, Rose-Anne, and Cuong Le Van, 2001, Optimal Control in Infinite Horizon, Typescript.

[3] Kamien, Morton, and Nancy Schwartz, 1991, Dynamic Optimization: The Calculus of Variations and Optimal Control in Economics and Management, second edition, North-Holland, Amsterdam.

[4] Leonard, Daniel, and Ngo Van Long, 1992, Optimal Control Theory and Static Optimization in Economics, Cambridge University Press, Cambridge and New York.

[5] Silberberg, Eugene, 1990, The Structure of Economics: A Mathematical Analysis, McGaw-Hill, New York.

[6] Takayama, Akira, 1985, Mathematical Economics, Second Edition, Cambridge University Press, Cambridge and New York. 


\section{Liste des publications au CIRANO*}

Série Scientifique / Scientific Series (ISSN 1198-8177)

2002s-04 A New Proof Of The Maximum Principle / Ngo Van Long et Koji Shimomura

2002s-03 Macro Surprises And Short-Term Behaviour In Bond Futures / Eugene Durenard et David Veredas

2002s-02 Financial Asset Returns, Market Timing, and Volatility Dynamics / Peter F. Christoffersen et Francis X. Diebold

2002s-01 An Empirical Analysis of Water Supply Contracts / Serge Garcia et Alban Thomas

2001s-71 A Theoretical Comparison Between Integrated and Realized Volatilities Modeling / Nour Meddahi

2001s-70 An Eigenfunction Approach for Volatility Modeling / Nour Meddahi

2001s-69 Dynamic Prevention in Short Term Insurance Contracts / M. Martin Boyer et Karine Gobert

2001s-68 Serial Cost Sharing in Multidimensional Contexts / Cyril Téjédo et Michel Truchon

2001s-67 Learning from Strike / Fabienne Tournadre et Marie-Claire Villeval

2001s-66 Incentives in Common Agency / Bernard Sinclair-Desgagné

2001s-65 Detecting Mutiple Breaks in Financial Market Volatility Dynamics / Elena Andreou et Eric Ghysels

2001s-64 Real Options, Preemption, and the Dynamics of Industry Investments / Marcel Boyer, Pierre Lasserre, Thomas Mariotti et Michel Moreaux

2001s-63 Dropout, School Performance and Working while in School: An Econometric Model with Heterogeneous Groups / Marcel Dagenais, Claude Montmarquette et Nathalie Viennot-Briot

2001s-62 Derivatives Do Affect Mutual Funds Returns : How and When? / Charles Cao, Eric Ghysels et Frank Hatheway

2001s-61 Conditional Quantiles of Volatility in Equity Index and Foreign Exchange Data / John W. Galbraith, Serguei Zernov and Victoria Zinde-Walsh

2001s-60 The Public-Private Sector Risk-Sharing in the French Insurance "Cat. Nat. System" / Nathalie de Marcellis-Warin et Erwann Michel-Kerjan

2001s-59 Compensation and Auditing with Correlated Information / M. Martin Boyer et Patrick González

2001s-58 Resistance is Futile: An Essay in Crime and Commitment / M. Martin Boyer

2001s-57 The Unreliability of Output Gap Estimates in Real Time / Athanasios Orphanides et Simon van Norden

2001s-56 Exact Nonparametric Two-Sample Homogeneity Tests for Possibly Discrete Distributions / Jean-Marie Dufour et Abdeljelil Farhat

2001s-55 Les coûts de la réglementation : une revue de la littérature / Robert Gagné, Paul Lanoie, Pierre-Carl Micheud et Michel Patry

\footnotetext{
* Consultez la liste complète des publications du CIRANO et les publications elles-mêmes sur notre site Internet :
} 
2001s-54 Testing for structural Change in the Presence of Auxiliary Models / Eric Ghysels et Alain Guay

2001s-53 Environmental Regulation and Productivity: New Findings on the Porter Hypothesis / Paul Lanoie, Michel Patry et Richard Lajeunesse

2001s-52 The Aftermarket Performance of Initial Public Offerings in Canada / Maher Kooli et Jean-Marc Suret

2001s-51 Capital Structure and Risk Management / Karine Gobert

2001s-50 The Underpricing of Initial Public Offerings: Futher Canadian Evidence / Maher Kooli et Jean-Marc Suret

2001s-49 How Innovative Are Canadian Firms Compared to Some European Firms? A Comparative Look at Innovation Surveys / Pierre Mohnen et Pierre Therrien

2001s-48 A Tale of Two Ports / Ngo Van Long et Kar-yiu Wong

2001s-47 Wage Policy of Firms: An Empirical Investigation / Stéphanie Lluis

2001s-46 Forecasting Some Low-Predictability Time Series Using Diffusion Indices / Marc Brisson, Bryan Campbell et John W. Galbraith

2001s-45 The Importance of the Loss Function in Option Pricing / Peter Christoffersen et Kris Jacobs

2001s-44 Let's Get "Real" about Using Economic Data / Peter Christoffersen, Eric Ghysels et Norman R. Swanson

2001s-43 Fragmentation, Outsourcing and the Service Sector / Ngo Van Long, Ray Riezman et Antoine Soubeyran

2001s-42 Nonlinear Features of Realized FX Volatility / John M. Maheu et Thomas H. McCurdy

2001s-41 Job Satisfaction and Quits: Theory and Evidence from the German Socioeconomic Panel / Louis Lévy-Garboua, Claude Montmarquette et Véronique Simonnet

2001s-40 Logique et tests d'hypothèse : réflexions sur les problèmes mal posés en économétrie / Jean-Marie Dufour

2001s-39 Managing IT Outsourcing Risk: Lessons Learned / Benoit A. Aubert, Suzanne Rivard et Michel Patry

2001s-38 Organizational Design of R\&D Activities / Stefan Ambec et Michel Poitevin 